\title{
FAKTOR-FAKTOR YANG MEMPENGARUHI MOTIVASI IBU DALAM PELAKSANAAN SENAM HAMIL DI WILAYAH KERJA PUSKESMAS CIPOCOK JAYA KOTA SERANG PROVINSI BANTEN TAHUN 2016
}

\author{
*Afni Yulianti, *Melly Halimatussaadiah
}

\begin{abstract}
Abstrak
Hasil SDKI 2012 menyebutkan angka kematian ibu (AKI) melonjak drastis 359 per 100 ribu kelahiran hidup. Padahal sebelumnya AKI dapat ditekan dari 390 per 100 Ribu kelahiran hidup (1991) menjadi 228 per 100 ribu kelahiran hidup (SDKI 2007). Angka Kematian Bayi (AKB) juga masih tinggi yaitu 32 per 1.000 kelahiran hidup. Senam hamil adalah terapi latihan gerak yang diberikan kepada ibu hamil untuk mempersiapkan dirinya, baik persiapan fisik maupun mental untuk mengahadapi dan mempersiapkan persalinan yang cepat, aman dan spontan (Huliana, 2001).Secara umum penelitian ini bertujuan untuk mengetahui faktor-faktor yang mempengaruhi motivasi ibu dalam pelaksanaan senam hamil di Wilayah Kerja Puskesmas Cipocok Jaya Kota Serang Provinsi Banten Tahun 2016.

Penelitian ini menggunakan metode survei analitik, dengan desain penelitian cross sectional (potong lintang), Populasi target dalam penelitian ini adalah seluruh ibu hamil Trimester II dan III di Wilayah Kerja Puskesmas Cipocok Jaya, Kota Serang. Jumlah Populasi penelitian ini adalah 115 orang Penelitian ini menggunakan teknik sampling, yaitu random sampling terhadap ibu hamil di Trimester II dan III di Wilayah Kerja Puskesmas Cipocok Jaya, Serang, Banten dan bersedia menjadi responden sebanyak 89 orang. Instrumen penelitian kuantitatif dan menggunakan data primer. Dalam penelitian ini dilakukan dengan memakai uji kai-kuadrat.

Hasil penelitian dari analisis univariat berdasarkan motivasi untuk melakukan senam hamil (76.4 \%), pengetahuan kurang terhadap senam hamil $(95,5 \%)$, tidak ada media yang menginformasikan tentang senam hamil $(76,4 \%)$, dukungan dari keluarga untuk melakukan senam hamil $(84,3 \%)$, sebagian kecil belum memiliki fasilitas untuk melakukan senam hamil $(43,8 \%)$. Hasil dari bivariate ada beberapa variabel memiliki hubungan yang bermakna antara lain yaitu media informasi dan fasilitas senam hamil dan ada variabel yang tidak terdapat hubungan yang bermakna yaitu pengetahuan dan dukungan keluarga. Secara bivariat diperoleh rata-rata $\mathrm{P}$ Value $=$ kurang dari $0,05(\mathrm{P}<\alpha)$ yang berarti terdapat hubungan yang signifikan dan sedangkan yang tidak berhubungan adalah paritas dengan hasil $\mathrm{P}$ Value $=$ lebih dari $0,05(\mathrm{P}>\alpha)$.

Pentingnya senam hamil bagi kesehatan ibu hamil maka diharapkan Puskesmas sebagai tempat pelayanan primer mampu memfasilitasi kegiatan senam hamil dan masyarakat mendukung terlaksananya kegiatan senam hamil secara rutin.
\end{abstract}

Kata Kunci : Faktor-faktor motivasi, senam hamil

*) Dosen Jurusan Kebidanan Poltekkes Kemenkes Banten 


\section{Pendahuluan}

Hasil Survei Demografi dan Kesehatan Indonesia (SDKI) menunjukkan gagalnya Indonesia mencapai target MDGs. Tujuan MDGs yang dimaksud yaitu untuk menurunkan AKI menjadi 102 per 100.000 kelahiran hidup. Diikuti angka AKB 23 kematian per 1000 kelahiran hidup di tahun 2015. Hasil SDKI 2012 menyebutkan angka kematian ibu (AKI) melonjak drastis 359 per 100 ribu kelahiran hidup. Padahal sebelumnya AKI dapat ditekan dari 390 per 100 Ribu kelahiran hidup (1991) menjadi 228 per 100 ribu kelahiran hidup (SDKI 2007)

Laporan dari SDKI tahun 2012 menyebutkan adanya peningkatan pelayanan kesehatan ibu, antara lain 96\% ibu hamil menerima pelayanan antenatal dari tenaga kesehatan dibandingkan pada tahun 2007 hanya $93 \%$, selain itu sekitar $83 \%$ persalinan dibantu oleh tenaga kesehatan sedangkan laporan SDKI tahun 2007 hanya 46\% yang menerima persalinannya dibantu oleh tenaga kesehatan.

Oleh karena itu penting dianjurkan pada ibu hamil untuk memeriksakan dirinya secara rutin dan teratur melalui perawatan selama masa kehamilan (antenatal care). Perawatan selama masa kehamilan (antenatal care) merupakan pemeriksaan kehamilan yang bertujuan untuk memeriksa keadaan ibu hamil dan janin secara berkala yang diikuti dengan upaya koreksi terhadap penyimpangan yang ditemukan.

Perilaku manusia sebenarnya merupakan refleksi dari berbagai gejala kejiwaan, diantaranya pengetahuan dan motivasi. Motivasi pada dasarnya merupakan interaksi seseorang dengan situasi tertentu yang dihadapinya. Di dalam diri seseorang terdapat "kebutuhan" (needs) atau "keinginan" (wants) terhadap objek di luar seseorang tersebut, kemudian bagaimana seseorang tersebut menghubungkan antara kebutuhan dengan "situasi di luar" objek tersebut dalam rangka memenuhi kebutuhan yang dimaksud. Oleh sebab itu, motivasi adalah suatu alasan (reasoning) seseorang untuk bertindak dalam rangka memenuhi kebutuhan hidupnya (Notoatmodjo, 2007).

Berdasarkan survey awal yang peneliti lakukan di Wilayah Kerja Puskesmas Cipocok Jaya Kota Serang Provinsi Banten Tahun 2016 terdapat 115 orang ibu hamil dengan usia kehamilan di Trimester II \& III, dari jumlah tersebut, 60 orang ibu hamil melakukan kegiatan senam hamil, namun sebagian lainnya tidak melakukan kegiatan senam hamil. Hasil wawancara singkat yang peneliti lakukan pada 5 orang ibu hamil yang tidak melakukan senam hamil. 


\section{Metode Penelitian}

Penelitian ini menggunakan metode survei analitik, dengan desain penelitian cross sectional (potong lintang), dimana hubungan variabel independen dan dependen diketahui/diukur pada saat bersamaan. Populasi target dalam penelitian ini adalah seluruh ibu hamil Trimester II dan III di Wilayah Kerja Puskesmas Cipocok Jaya, Kota Serang, Banten. Jumlah Populasi penelitian ini adalah 115 orang. Teknik pengambilan sampel dalam penelitian ini adalah dengan cara acak (simple random sampling), yaitu pengambilan sampel dimana semua individu dalam polpulasi baik secara sendiri - sendiri atau bersama-sama diberi kesempatan yang sama untuk dipilih sebagai anggota sampel.

\section{Hasil}

\section{Analisis Univariat}

Tabel 1

Distribusi Frekuensi Motivasi Ibu Hamil Melakukan Senam Hamil di Wilayah Kerja Puskesmas Cipocok Jaya Kota Serang Tahun 2016

\begin{tabular}{lcc}
\hline \multicolumn{1}{c}{ Motivasi } & Jumlah & Persentase \\
\hline Kurang & 68 & 76,4 \\
Kuat & 21 & 23,6 \\
\hline Total & 89 & 100
\end{tabular}

Berdasarkan tabel 1 diketahui bahwa sebagian besar ibu hamil kurang motivasi untuk melakukan senam hamil (76.4\%).
Tabel 2

Distribusi Frekuensi Pengetahuan Ibu Hamil tentang Senam Hamil di Wilayah Kerja Puskesmas Cipocok Jaya Kota Serang Tahun 2016

\begin{tabular}{lcc}
\hline Pengetahuan & Jumlah & Persentase \\
\hline Kurang & 85 & 95,5 \\
Baik & 4 & 4,5 \\
\hline Total & 89 & 100 \\
\hline
\end{tabular}

Berdasarkan tabel 2 diatas menunjukan bahwa sebagian besar ibu hamil memiliki pengetahuan kurang terhadap senam hamil $(95,5 \%)$.

Tabel 3

Distribusi Frekuensi Media Informasi tentang Senam Hamil di Wilayah Kerja Puskesmas Cipocok Jaya Kota Serang Tahun 2016

\begin{tabular}{lcc}
\hline $\begin{array}{l}\text { Media } \\
\text { Informasi }\end{array}$ & Jumlah & Persentase \\
\hline Tidak ada & 68 & 76,4 \\
Ada & 21 & 23,6 \\
\hline Total & 89 & 100 \\
\hline
\end{tabular}

Pada tabel 3 diatas menunjukkan bahwa sebagian besar tidak ada media yang menginformasikan tentang senam hamil $(76,4 \%)$ 
Tabel 4

Distribusi Frekuensi Dukungan Keluarga terhadap Senam Hamil di Wilayah Kerja

Puskesmas Cipocok Jaya Kota Serang

Tahun 2016

\begin{tabular}{lcc}
\hline $\begin{array}{l}\text { Dukungan } \\
\text { Keluarga }\end{array}$ & Jumlah & Persentase \\
\hline Tidak ada & 14 & 15,7 \\
Ada & 75 & 84,3 \\
\hline Total & 89 & 100 \\
\hline
\end{tabular}

Pada tabel diatas menunjukkan

bahwa sebagian besar ibu hamil memiliki dukungan dari keluarga untuk melakukan senam hamil $(84,3 \%)$

Tabel 5

Distribusi Frekuensi Fasilitas Senam Hamil di Wilayah Kerja Puskesmas Cipocok Jaya Kota Serang Tahun 2016

\begin{tabular}{lcc}
\hline Fasilitas & Jumlah & Persentase \\
Senam Hamil & & \\
\hline Tidak ada & 39 & 43,8 \\
Ada & 50 & 56,2 \\
\hline Total & 89 & 100 \\
\hline
\end{tabular}

Pada tabel di atas menunjukkan bahwa Wilayah Kerja Puskesmas Cipocok Jaya sebagian kecil belum memiliki Fasilitas untuk melakukan senam hamil $(43,8 \%)$
2. Analisis Bivariat

Tabel 6

Pengaruh pengetahuan terhadap motivasi ibu hamil melakukan senam hamil di Wilayah Kerja Puskesmas Cipocok Jaya Kota Serang Tahun 2016

\begin{tabular}{lcccc}
\hline $\begin{array}{l}\text { Penge } \\
\text { tahuan }\end{array}$ & \multicolumn{2}{c}{ Motivasi } & Jumlah & Purang \\
& & Kuat & & Value \\
\hline Kurang & 64 & 21 & 85 & 0.569 \\
& $75.3 \%$ & $24.7 \%$ & $100 \%$ & \\
Baik & 4 & 0 & 4 & \\
& $100 \%$ & $0.0 \%$ & $100 \%$ & \\
Jumlah & 68 & 21 & 89 & \\
& $76.4 \%$ & $23.6 \%$ & $100 \%$ & \\
\hline
\end{tabular}

Dari tabel di atas menunjukkan bahwa terdapat 64 orang ibu hamil $(75,3 \%)$ berpengetahuan kurang dan memiliki motivasi yang kurang untuk melakukan senam hamil, sedangkan ibu hamil yang memiliki pengetahuan baik dan memiliki motivasi yang kurang sebanyak 4 orang $(100 \%)$.

Hasil uji statistik dengan menggunakan uji Chi Square pada $\alpha=0,05$ didapatkan nilai $\mathrm{P}$ sebesar 0,569 $(\mathrm{P}>0,05)$ yang berarti secara statistik tidak terdapat pengaruh yang bermakna antara pengetahuan dengan motivasi ibu hamil untuk melakukan senam hamil di Wilayah Kerja Puskesmas Cipocok Jaya Kota Serang Tahun 2016. 
Tabel 7

Pengaruh media informasi terhadap motivasi ibu hamil melakukan senam hamil di Wilayah Kerja Puskesmas Cipocok Jaya Kota Serang Tahun 2016

\begin{tabular}{lcccc}
\hline Media & \multicolumn{2}{c}{ Motivasi } & Jumlah & P \\
Informasi & Kurang & Kuat & & Value \\
& & & & \\
\hline Ada & 9 & 12 & 21 & 0.000 \\
& $42.9 \%$ & $57.1 \%$ & $100 \%$ & \\
Tidak & 59 & 9 & 68 & \\
Ada & $86.8 \%$ & $13.2 \%$ & $100 \%$ & \\
Jumlah & 68 & 21 & 89 & \\
& $76.4 \%$ & $23.6 \%$ & $100 \%$ & \\
\hline
\end{tabular}

Dari tabel diatas menunjukkan bahwa terdapat 9 orang (42,9\%) mendapatkan informasi melalui media dan memiliki motivasi yang kurang melakukan senam hamil, sedangkan 59 orang $(86,8 \%)$ tidak mendapatkan informasi dari media dan memiliki motivasi yang kurang melakukan senam hamil.

Hasil uji statistik dengan menggunakan uji Chi Square pada $\alpha=0,05$ didapatkan nilai $\mathrm{P}$ sebesar $0,000(\mathrm{P}<0,05)$ yang berarti secara statistik terdapat pengaruh yang bermakna antara media informasi dengan motivasi ibu hamil untuk melakukan senam hamil di Wilayah Kerja Puskesmas Cipocok Jaya Kota Serang Tahun 2016.
Tabel. 8

Pengaruh dukungan keluarga terhadap motivasi ibu hamil melakukan senam hamil di Wilayah Kerja Puskesmas Cipocok Jaya Kota Serang Tahun 2016

\begin{tabular}{ccccc}
\hline $\begin{array}{c}\text { Dukungan } \\
\text { Keluarga }\end{array}$ & \multicolumn{2}{c}{ Motivasi } & Jumlah & P \\
& Kurang & Kuat & & Value \\
\hline Tidak ada & 8 & 6 & 14 & 0.087 \\
& $57.1 \%$ & $42.9 \%$ & $100 \%$ & \\
Ada & 60 & 15 & 75 & \\
& $80 \%$ & $20 \%$ & $100 \%$ & \\
\cline { 1 - 4 } Jumlah & 68 & 21 & 89 & \\
& $76.4 \%$ & $23.6 \%$ & $100 \%$ & \\
\hline
\end{tabular}

Dari tabel di atas menunjukkan bahwa kurangnya motivasi melakukan senam hamil dan tidak mendapatkan dukungan keluarga sebanyak 8 orang $(57,1$ $\%)$ lebih kecil dibandingkan pada ibu hamil yang memiliki motivasi kurang dan mendapat dukungan keluarga sebanyak 60 orang $(80 \%)$.

Hasil uji statistik dengan menggunakan uji Chi Square pada $\alpha=0,05$ didapatkan nilai $\mathrm{P}$ sebesar 0,087 $(\mathrm{P}>0,05)$ yang berarti secara statistik tidak terdapat pengaruh yang bermakna antara dukungan keluarga dengan motivasi ibu hamil untuk melakukan senam hamil di Wilayah Kerja Puskesmas Cipocok Jaya Kota Serang Tahun 2016. 
Tabel 9

Pengaruh Ketersediaan Fasilitas Senam

Hamil terhadap motivasi ibu hamil melakukan senam hamil di Wilayah Kerja

Puskesmas Cipocok Jaya Kota Serang Tahun 2016

\begin{tabular}{lcccc}
\hline Fasilitas & \multicolumn{2}{c}{ Motivasi } & Jumlah & P \\
Senam & Kurang & Kuat & & Value \\
Hamil & & & & \\
\hline Ada & 32 & 18 & 50 & 0.004 \\
& $64 \%$ & $36 \%$ & $100 \%$ & \\
Tidak Ada & 36 & 3 & 39 & \\
& $92.3 \%$ & $7.7 \%$ & $100 \%$ & \\
Jumlah & 68 & 21 & 89 & \\
& $76.4 \%$ & $23.6 \%$ & $100 \%$ & \\
\hline
\end{tabular}

Dari tabel 9 di atas menunjukkan bahwa kurangnya motivasi ibu hamil dan menyatakan tidak ada fasilitas senam hamil sebanyak 36 orang $(92,3 \%)$ lebih besar dibandingkan dengan ibu hamil yang memiliki motivasi kurang dan menyatakan terdapat fasilitas senam hamil sebanyak 32 orang $(64 \%)$.

Hasil uji statistik dengan menggunakan uji Chi Square pada $\alpha=0,05$ didapatkan nilai $\mathrm{P}$ sebesar $0,004(\mathrm{P}<0,05)$ yang berarti secara statistik terdapat pengaruh yang bermakna antara fasilitas senam hamil dengan motivasi ibu hamil untuk melakukan senam hamil di Wilayah Kerja Puskesmas Cipocok Jaya Kota Serang Tahun 2016.

\section{Pembahasan}

1. Motivasi Ibu hamil

Berdasarkan hasil penelitian, diketahui bahwa sebagian besar ibu hamil kurang motivasi untuk melakukan senam hamil $(76.4 \%)$.

Motivasi dilakukan sedang apabila dalam diri manusia memiliki keinginan yang positif, mempunyai harapan yang tinggi, namun memiliki keyakinan yang rendah bahwa dirinya dapat bersosialisasi dan mampu menyelesaikan persoalan yang dihadapi.(Irwanto, 2008)

Menurut Notoatmojo (2003) faktor yang mempengaruhi Motivasi kurang untuk melakukan senam hamil adalah Faktor fisik, proses mental, herediter, lingkungan, kematangan usia, fasilitas (sarana dan prasarana), media. Jadi dapat disimpulkan bahwa motivasi ibu hamil kurang dipengaruhi beberapa faktor tersebut di atas.

2. Pengaruh Pengetahuan Terhadap Motivasi Ibu Hamil Melakukan Senam Hamil

Berdasarkan hasil penelitian, diketahui bahwa sebagian besar ibu hamil yang memiliki motivasi kurang untuk melakukan senam hamil memiliki pengetahuan yang kurang tentang senam hamil $(75,3 \%)$.

Hasil uji statistik dengan menggunakan uji Chi Square pada $\alpha=0,05$ didapatkan nilai $\mathrm{P}$ sebesar $0,569(\mathrm{P}>0,05)$ yang berarti secara statistik tidak terdapat pengaruh yang bermakna antara pengetahuan dengan motivasi ibu hamil 
untuk melakukan senam hamil di Wilayah Kerja Puskesmas Cipocok Jaya Kota Serang Tahun 2016.

Pengetahuan adalah hasil penginderaan manusia, atau hasil tahu seseorang terhadap objek melalui indera yang dimilikinya (mata, hidung, telinga, dan sebagainya) (Notoatmodjo, 2010).

Menurut Notoatmodjo (2010), ada beberapa faktor yang mempengaruhi pengetahuan seseorang yaitu: pendidikan, media masa, sosial budaya dan ekonomi, lingkungan, pengalaman.

Pengetahuan merupakan domain yang cukup penting dalam pembentukan perilaku pada diri seseorang (Notoatmodjo, 2007). Ibu yang memiliki pengetahuan kurang, belum tentu tidak ada yang memiliki motivasi kuat, hal ini dibuktikan dari hasil penelitian bahwa pada ibu hamil yang berpengetahuan kurang masih ditemukan ibu yang bermotivasi kuat $(23,6 \%)$.

3. Pengaruh Media Massa/Sumber Informasi Terhadap Motivasi Ibu Hamil Melakukan Senam Hamil

Berdasarkan hasil penelitian, diketahui bahwa sebagian besar ibu hamil yang memiliki motivasi kurang untuk melakukan senam hamil tidak memperoleh informasi dari media massa/sumber informasi mengenai senam hamil $(86,8 \%)$.
Hasil uji statistik dengan menggunakan uji Chi Square pada $\alpha=0,05$ didapatkan nilai $\mathrm{P}$ sebesar $0,000(\mathrm{P}<0,05)$ yang berarti secara statistik terdapat pengaruh yang bermakna antara media informasi dengan motivasi ibu hamil untuk melakukan senam hamil di Wilayah Kerja Puskesmas Cipocok Jaya Kota Serang Tahun 2016.

Sumber informasi merupakan banyaknya informasi yang pernah diperolah ibu mengenai Senam hamil. Menurut Notoatmodjo (2007), salah satu faktor yang mempengaruhi pengetahuan seseorang tentang sesuatu hal adalah banyaknya informasi yang pernah diperoleh mengenai sesuatu hal tersebut.

Adapun sumber informasi dapat diperoleh melalui media massa, seperti media cetak (Koran, majalah, buku, tabloid, dan sebagainya), dan media elektronik (televisi, radio, internet), maupun melalui petugas kesehatan. (Notoatmodjo, 2007).

Dengan pengetahuan yang diperoleh tersebut akan berpengaruh terhadap motivasi ibu hamil terhadap senam hamil yang dilakukannya.

4. Pengaruh Dukungan Keluarga Terhadap Motivasi Ibu Hamil Melakukan Senam Hamil

Berdasarkan hasil penelitian, diketahui bahwa sebagian besar ibu hamil yang memiliki motivasi kurang untuk 
melakukan senam hamil mendapatkan dukungan keluarga untuk melakukan senam hamil $(80 \%)$.

Hasil uji statistik dengan menggunakan uji Chi Square pada $\alpha=0,05$ didapatkan nilai $\mathrm{P}$ sebesar 0,087 $(\mathrm{P}>0,05)$ yang berarti secara statistik tidak terdapat pengaruh yang bermakna antara dukungan keluarga dengan motivasi ibu hamil untuk melakukan senam hamil di Wilayah Kerja Puskesmas Cipocok Jaya Kota Serang Tahun 2016.

Dukungan keluarga menurut Friedman (2010) adalah sikap, tindakan dan penerimaan keluarga terhadap anggota keluarga, berupa dukungan informasional, dukungan penilaian, dukungan instrumental dan dukungan emosional. Jadi dukungan keluarga adalah suatu bentuk hubungan interpersonal 25 yang meliputi sikap, tindakan dan penerimaan terhadap anggota keluarga, sehingga anggota keluarga merasa ada yang memperhatikan.

Tidak terdapat pengaruh yang bermakna antara dukungan keluarga dengan motivasi ibu hamil dapat dilihat pada tabel 4.8 bahwa ibu hamil yang mendapatkan dukungan keluarga mempunyai motivasi yang kurang untuk melakukan senam hamil, begitu pula sebaliknya ibu hamil yang tidak mendapat dukungan keluarga masih ditemukan ibu hamil yang memiliki motivasi kuat untuk melakukan senam hamil sebesar (6,7\%). Kemungkinan mengapa sebagian besar ibu hamil yang diberi dukungan oleh keluarga memiliki motivasi yang kurang dikarenakan pengetahuan ibu yang kurang tentang manfaat senam hamil $(71,9 \%)$ dan keluaraga tidak menjelaskan secara menyeluruh mengenai manfaat senam hamil serta kurangnya informasi tentang fasilitas (sarana dan prasarana) untuk melaksanakan senam hamil (40,4\%). Bagaimanapun besarnya pengaruh lingkungan jika tidak ada sarana dan prasarananya tidak akan menumbuhkan motivasi yang kuat untuk melakukan senam hamil.

5. Pengaruh ketersediaan fasilitas (sarana prasarana) senam hamil terhadap motivasi ibu hamil melakukan senam hamil

Dari tabel 9 diatas menunjukkan bahwa sebagian besar ibu hamil yang memiliki motivasi kurang untuk melakukan senam hamil dikarenakan tidak ada fasilitas senam hamil sebanyak $(92,3 \%)$.

Hasil uji statistik dengan menggunakan uji Chi Square pada $\alpha=0,05$ didapatkan nilai $\mathrm{P}$ sebesar $0,004(\mathrm{P}<0,05)$ yang berarti secara statistik terdapat pengaruh yang bermakna antara fasilitas senam hamil dengan motivasi ibu hamil untuk melakukan senam hamil di Wilayah Kerja Puskesmas Cipocok Jaya Kota Serang Tahun 2016. 
Pengertian Fasilitas Menurut Daradjat "Fasilitas" adalah segala sesuatu yang dapat mempermudah upaya dan memperlancar kerja dalam rangka mencapai suatu tujuan. Ada beberapa pendapat tentang fasilitas, Subroto berpendapat "Fasilitas" adalah segala sesuatu yang dapat memudahkan dan memperlancar pelaksanaan suatu usaha dapat berupa benda-benda maupun uang. Arikunto berpendapat, "Fasilitas" dapat diartikan sebagai segala sesuatu yang dapat memudahkan dan memperlancar pelaksanaan segala sesuatu usaha. Adapun yang dapat memudahkan dan melancarkan usaha ini dapat berupa benda - benda maupun uang, jadi dalam hal ini fasilitas dapat disamakan dengan sarana dan prasarana dalam pelaksanaan senam hamil.

Tidak adanya fasilitas untuk pelaksanaan senam hamil jelas akan menurunkan motivasi ibu untuk melakukan senam hamil.

\section{Simpulan}

1. Berdasarkan hasil penelitian, diketahui bahwa sebagian besar ibu hamil kurang motivasi untuk melakukan senam hamil (76.4\%).

2. Berdasarkan hasil penelitian, diketahui bahwa sebagian besar ibu hamil memiliki pengetahuan kurang terhadap senam hamil $(95,5 \%)$
3. Berdasarkan hasil penelitian, diketahui sebagian besar tidak ada media yang menginformasikan tentang senam hamil $(76,4 \%)$

4. Berdasarkan hasil penelitian, diketahui sebagian besar ibu hamil memiliki dukungan dari keluarga untuk melakukan senam hamil $(84,3 \%)$

5. Berdasarkan hasil penelitian, diketahui Wilayah Kerja Puskesmas Cipocok Jaya sebagian kecil belum memiliki Fasilitas (sarana dan prasarana) untuk melakukan senam hamil $(43,8 \%)$

6. Berdasarkan hasil penelitian, diketahui bahwa sebagian besar ibu hamil yang memiliki motivasi kurang untuk melakukan senam hamil memiliki pengetahuan yang kurang tentang senam hamil (75,3\%). Berdasarkan hasil penelitian, diketahui bahwa sebagian besar ibu hamil yang memiliki motivasi kurang untuk melakukan senam hamil tidak memperoleh informasi mengenai senam hamil $(86,8 \%)$.

7. Berdasarkan hasil penelitian, diketahui bahwa sebagian besar ibu hamil yang memiliki motivasi kurang untuk melakukan senam hamil dikarenakan tidak ada fasilitas senam hamilnya $(92,3 \%)$. 


\section{Daftar Pustaka}

Agudelo. 2007. Menyiapkan kehamilan kedua. Jakarta. http://www.conectique.com

Cangara, Hafied. 2002. Pengantar Ilmu Komunikasi. PT RajaGrafindo Persada, Jakarta

Dewi, Vivian Nanny Lia \& Tri Sunarsih. 2011. Asuhan Kehamilan untuk Kebidanan. Jakarta: Salemba.

Elliot, S.N., Kratochwill, T.R., Littelfield Cook, J \& Travers, J. 2000. Educational psychology : Effective teaching, effective learning (3rd ed). Boston, MA: McGraw-Hill College.

Fajar, Ibnu dkk. 2009. Statistik untuk praktisi kesehatan. Yogyakarta: Graha Ilmu.

Hidayat, AA. 2010. Metode Penelitian Kebidanan \& Teknik Analisis Data. Jakarta: Salemba Medika.

Laporan MDG's. 2008. Mari kita suarakan MDG's. Bappenas. Jakarta.

Simkin, Penny. 2007. Panduan lengkap : Kehamilan, melahirkan \& bayi. Jakarta: Arcan.

Mandriawati. 2008. Penuntun Belajar Asuhan Kebidanan Ibu Hamil. Jakarta: EGC.

Manuaba, I.B.G. 2010. Ilmu Kebidanan, Penyakit Kandungan \& Keluarga Berencana untuk Pendidikan Bidan. Jakarta: EGC.

Mc.Quail, Dennis. 2005. Teori Komunikasi Massa. Erlangga, Jakarta
Notoatmodjo, S. (2007) Metode Penelitian Kesehatan, edisi revisi, Rineke Cipta. Jakarta.

Notoatmodjo, Soekidjo. 2010. Metodologi Penelitian Kesehatan. Jakarta: Rineka Cipta.

Santoso, S. 2010. Statistik multivariat konsep dan aplikasi dengan SPSS.Jakarta: PT Elex Media Komputindo.

Scoff, Judith \& Judy Priest. 2008. Kelas Antenatal. alih bahasa Nike Budhi Subekti. Jakarta: EGC.

Sulistiyawati, Ari. 2008. Asuhan kebidanan pada kehamilan. Jakarta: Salemba Medika.

SDKI. 2012. Survey Demografi dan Kesehatan Indonesia. Jakarta 